\title{
Chalcone and Flavonol Copper(II) Complexes Containing Schiff Base Co-Ligand: Synthesis, Crystal Structures and Catecholase-like Activity
}

\author{
Emira Kahrović, ${ }^{1, *}$ Adnan Zahirović, ${ }^{1}$ Aleksandar Višnjevac, ${ }^{2, \#}$ Irnesa Osmanković, ${ }^{1}$ Emir Turkušić, ${ }^{1}$ Harun Kurtagić ${ }^{3}$
}

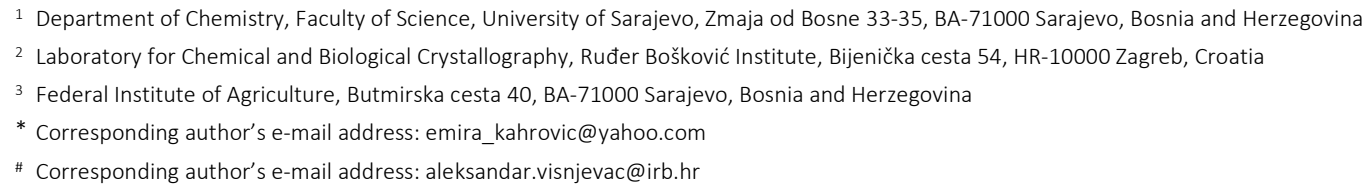

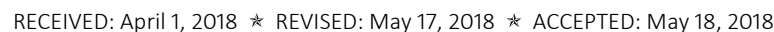

THIS PAPER IS DEDICATED TO DR. BISERKA KOJIĆ-PRODIĆ ON THE OCCASION OF HER 80

\begin{abstract}
Four new heteroleptic copper(II) complexes having chalcone or flavonol ligands and Schiff base ( $\mathrm{N}$-phenyl-5-chlorosalicylideneimine) as co-ligand were prepared, chemically and structurally characterized and investigated as functional biomimetic catecholase models. The complexes were prepared by the solution synthesis and crystal and molecular structures were determined by X-ray diffraction. Complexes were chemically characterized by elemental analysis, infrared and electronic absorption spectroscopy as well as by electrochemical measurements. Copper(II) chalcone complexes, with square-pyramidal $\mathrm{CuO}_{4} \mathrm{~N}$ core, are binuclear, featuring phenolate oxygen from the Schiff base as a bridging atom, while copper(II) flavonol complexes are mononuclear, and reveal a square planar $\mathrm{CuO}_{3} \mathrm{~N}$ coordination core. Catalytic activity of the complexes in 3,5-di-tert-butylcatechol oxidation was confirmed by spectrophotometric and electrochemical measurements. Kinetic measurements revealed that the binuclear (chalcone-containing) complexes have enhanced catalytic activity as compared to the mononuclear $\mathrm{Cu}$ (II) flavonol complexes. Relatively high $k_{\text {cat }}$ values $\left(300-750 \mathrm{~h}^{-1}\right)$ confirmed their respectable biomimetic catecholase-like activity.
\end{abstract}

Keywords: copper, Schiff base, chalcone, flavonol, catecholase activity.

\section{INTRODUCTION}

$\mathbf{T}$ HE development of the novel metal complexes with innovative structures and reactivity in different biological environments attracts huge attention, primarily due to an important role that metals play in various biochemical processes. The molecular design of many novel small inorganic metal complexes is, therefore, inspired by the structural features of the metalloenzyme active sites. These complexes are recognized as biomimetic, and are developed with an ultimate goal to translate structural resemblances with biological originals to the functional ones. ${ }^{[1]}$ Copper, an essential trace bioelement, is found in proteins in its two generally most common oxidation states: $\mathrm{Cu}(\mathrm{I})$ and $\mathrm{Cu}(\mathrm{II})$. As a redox active element, copper is involved in plethora of (bio)catalytic reactions. ${ }^{[2]} \mathrm{A}$ large number of copper complexes described in the literature differ in nuclearity, geometry and type of the ligands. Copper(I) complexes are usually tetrahedral, while $\mathrm{Cu}(\mathrm{II})$ adopts square-planar, distorted tetrahedral, square pyramidal, trigonal bipyramidal or distorted octahedral coordination. ${ }^{[3]}$ The ability to expand its coordination number by reversibly binding the substrate, along with its redox activity, makes copper an ideal candidate to design catalytic complexes. Copper complexes attract great attention as the model systems for copper containing enzymes. Catechol oxidases, which feature active site belonging to the type-3 binuclear copper sites, catalyze the oxidation of different ortho-diphenols to corresponding ortho-diquinones which further polymerize to melanin, an important skin protecting pigment. ${ }^{[4]}$ In the catecholase native form, a monohydroxo bridged copper atoms are 
coordinated by three imidazole nitrogen atoms from the histidine residues. ${ }^{[5-7]}$

The studies of copper complexes with catecholaselike activity include structural, mechanistic and kinetic approaches. The structural aspect is mainly focused on the significance of $\mathrm{Cu}-\mathrm{Cu}$ distance, ranging from $2.9-3.2 \AA$ in naturally occurring enzymes. ${ }^{[8]}$ Significance of two close metal centers is ascribed to the enhanced binding of the catechol oxygen atoms prior to oxidation. ${ }^{[9]}$ Many copper complexes are therefore designed to have $\mathrm{Cu}-\mathrm{Cu}$ distances in this range, although a number of binuclear complexes with significantly larger inter-copper distances, as well as different mononuclear copper complexes, were reported to demonstrate an ability to catalyze the oxidation of catechol to quinone. ${ }^{[10-12]}$

Schiff bases are very flexible and widely used ligands in the coordination chemistry of many transition elements, forming stable complexes with various applications in different fields. ${ }^{[13,14]}$ One attractive use in the coordination chemistry has been to investigate the ability of these imines to act as phenoxo-bridging ligands in binuclear metal complexes. ${ }^{[15,16]}$ Having azomethine group and other hard or soft donor atoms, Schiff bases are suitable to tune metal redox potential as the crucial parameter in many biochemical processes. A number of copper Schiff base complexes were reported to catalyze different chemical processes. ${ }^{[17-23]}$ Several mononuclear and binuclear copper(II) Schiff base complexes are reported for their catalytic activity in 3,5-di-tert-butylcatechol (DTBC) oxidation. ${ }^{[24,25]}$ On the other hand, the copper complexes containing flavonols or chalcones were not extensively investigated, mainly having in the focus their antioxidative, antibacterial and nuclease-like activity. ${ }^{[26-28]}$

We report hereby the synthesis, chemical and structural characterization of novel chalcone and flavonol copper(II) complexes $\mathbf{1} \mathbf{- 4}$ with the Schiff base co-ligand, as well as the study of their catalytic activity towards the 3,5-di-tert-butylcatechol oxidation.

\section{EXPERIMENTAL SECTION}

\section{Materials}

All chemicals were commercially available and used as received if not otherwise indicated. Copper(II) acetate hydrate, 2'-hydroxyacetophenone, 5-chlorosalicylaldehyde, benzaldehyde and 3-hydroxybenzaldehyde were obtained as reagent grade chemicals from Sigma. Aniline was vacuum distilled prior the use. The 3,5-di-tert-butylcatechol $(98 \% w / w)$ was obtained from Sigma and used without further purification. Anhydrous DMSO (water content < $0.005 \%$ ) and anhydrous methanol (water content < $0.002 \%$ ) were supplied from commentarial sources.

\section{Physical Measurements}

Elemental analysis was performed on a Perkin Elmer 2400 Series CHNS/O analyzer. Infrared spectra were collected as $\mathrm{KBr}$ pallets in the $4000-400 \mathrm{~cm}^{-1}$ region with a Perkin Elmer BX FTIR. Electronic spectra were acquired in the $200-700 \mathrm{~nm}$ range in methanol $\left(1.25 \times 10^{-5} \mathrm{~mol} \mathrm{dm}^{-3}\right)$ on a Perkin Elmer Lambda 35.

Electrochemical measurements were performed at an Autolab potentiostat / galvanostat (PGSTAT 12) electrochemical workstation using a three electrode system with a glassy carbon as working, a Pt wire as counter and $\mathrm{Ag} / \mathrm{AgCl}$ as a reference electrode connected to the working solution via salt bridge. Cyclic voltammograms of the complexes $\left(\sim 10^{-4} \mathrm{~mol} \mathrm{dm}^{-3}\right)$ and ligands $\left(\sim 10^{-4} \mathrm{~mol} \mathrm{dm}^{-3}\right)$ were recorded in dry DMSO in the -0.6 to $+1.0 \mathrm{~V}$ potential range at a $100 \mathrm{mV} \mathrm{s}^{-1}$ scan rate.

\section{Ligands Syntheses}

The ligands were prepared by the standard methods for these classes of compounds. Schiff base (HL), N-phenyl-5chlorosalicylideneimine, was obtained by the condensation of aniline and 5-chlorosalicylaldehyde. ${ }^{[16]}$ Chalcones ( $\mathrm{HL}^{1}$, $\mathrm{HL}^{2}$ ) were prepared by the condensation reaction between 2'-hydroxyacetophenone and benzaldehyde or 4-hydroxybenzaldehyde in the presence of aqueous sodium hydroxide. ${ }^{[29]}$ The oxidation of chalcones with the alkaline hydrogen peroxide was used as a convenient method for the synthesis of flavonol ligands $\left(\mathrm{HL}^{3}, \mathrm{HL}^{4}\right) .^{[30]}$

Synthesis of Schiff Base Ligand, HL. To a warm ethanol solution $(20 \mathrm{~mL})$ of 5 -chlorosalicylaldehyde $(4.32 \mathrm{mmol}$; $676 \mathrm{mg}$ ) freshly distilled aniline $(4.32 \mathrm{mmol}, 393 \mu \mathrm{L})$ and one drop of conc. sulfuric acid were added. The reaction mixture was refluxed over two hours. Upon cooling, orange needles of $\mathrm{N}$-phenyl-5-chlorosalicylideneimine were collected by filtration and washed with ice cold ethanol $(10 \mathrm{~mL})$. Yield: $740 \mathrm{mg}$ (74\%).

Syntheses of Chalcone Ligands, $\mathrm{HL}^{1}$ and $\mathrm{HL}^{2}$. Benzaldehyde or 3-hydroxybenzaldehyde $(20 \mathrm{mmol})$ and 2'-hydroxyacetophenone $(20 \mathrm{mmol} ; 2.41 \mathrm{~mL}$ ) were dissolved in ethanol $(20 \mathrm{~mL})$ and sodium hydroxide $\left(17.2 \mathrm{~mL}, 5 \mathrm{~mol} \mathrm{dm}^{-3}\right)$ was added. The reaction mixture was stirred over 24 hours at the room temperature. The solution was thereupon acidified by an addition of acetic acid ( $30 \% \mathrm{w} / \mathrm{w})$ until $\mathrm{pH}=6$ was obtained. The chalcone was separated by suction, washed twice with water and vacuum dried over silica. Yield: $3.53 \mathrm{~g}$ (79\%) for $\mathrm{HL}^{1}$; $3.21 \mathrm{~g}(67 \%)$ for $\mathrm{HL}^{2}$.

Syntheses of Flavonol Ligands, $\mathbf{H L}^{3}$ and $\mathbf{H L}^{4}$. The appropriate chalcone, 2'-hydroxychalcone or 2',3-dihydroxychalcone $(10 \mathrm{mmol})$ was suspended in ethanol $(20 \mathrm{~mL})$ and aqueous sodium hydroxide $\left(4 \mathrm{~mL}, 5 \mathrm{~mol} \mathrm{dm}^{-3}\right)$ was added until the complete dissolution of the chalcone. Resulting 
yellow solution was cooled to $0{ }^{\circ} \mathrm{C}$ after which hydrogen peroxide $(2.53 \mathrm{~mL}, 30 \% \mathrm{w} / \mathrm{w})$ was added dropwise. The reaction mixture was stirred over 24 hours at room temperature, acidified to $\mathrm{pH}=1$ with $2 \mathrm{~mol} \mathrm{dm}^{-3} \mathrm{HCl}$ and poured into $200 \mathrm{~mL}$ of ice cold water. The flavonol was filtered off, washed with water and ice-cold ethanol and vacuum dried. Yield: $2.12 \mathrm{~g}(89 \%)$ for $\mathrm{HL}^{3} ; 2.13 \mathrm{~g}(84 \%)$ for $\mathrm{HL}^{4}$.

\section{Syntheses of Copper(II) Complexes, 1 - 4}

Methanol solution $(40 \mathrm{~mL})$ containing Schiff base $(0.5 \mathrm{mmol}$, $116 \mathrm{mg}$ ) and the appropriate chalcone or flavonol ligand (0.5 mmol; $120 \mathrm{mg} \mathrm{HL}^{1}, 127 \mathrm{mg} \mathrm{HL}{ }^{2}, 112 \mathrm{mg} \mathrm{HL}{ }^{3}, 119 \mathrm{mg}$ $\mathrm{HL}^{4}$ ) was added to the methanol solution $(25 \mathrm{~mL})$ of the copper(II) acetate dihydrate $(0.25 \mathrm{mmol}, 100 \mathrm{mg})$. The reaction mixture was refluxed over one hour, filtered off while hot and left to evaporate at the room temperature. After three days crystals of $\mathbf{1 - 4}$ were collected by suction, washed with ice-cold methanol and air dried. Single crystals suitable for X-ray diffraction were obtained directly from reaction mixture (2 and $\mathbf{3}$ ), or by recrystallization from hot DMF (1) or methanol (4).

Complex 1. bis[(E)-1-(2-oxy-kO-phenyl)-3-phenyl-prop-2en-1-on(1-)-kO]bis[(E)-4-chloro-2-((phenylimino-kN)methyl)$\mu$-phenolato(1-)-kO)copper(II)]; $170 \mathrm{mg}$ (66 \%); UV-Vis (MeOH) $\lambda_{\max } / \mathrm{nm:} 236$ and $306\left(\log \varepsilon / \mathrm{dm}^{3} \mathrm{~mol}^{-1} \mathrm{~cm}^{-1}: 4.82\right.$ and 4.70); IR (KBr), $v_{\max } / \mathrm{cm}^{-1}: 1627(\mathrm{C}=\mathrm{O}), 1618(\mathrm{C}=\mathrm{C}), 1592$ $(\mathrm{C}=\mathrm{N}), 1290(\mathrm{C}-\mathrm{O}), 608,549(\mathrm{Cu}-\mathrm{O}), 413(\mathrm{Cu}-\mathrm{N})$; Anal. Calcd. mass fractions of elements, $w / \%$, for $\mathrm{C}_{56} \mathrm{H}_{40} \mathrm{Cl}_{2} \mathrm{~N}_{2} \mathrm{O}_{6} \mathrm{Cu}_{2}$ $(\mathrm{Mr}=1034.92)$ are: C64.99, H3.90, N2.90; found: C64.97, H4.27, N2.89.

Complex 2. bis[(E)-1-(2-oxy-kO-phenyl)-3-(4-hydroxyphenyl)prop-2-en-1-on(1-)-kO]bis[(E)-4-chloro-2-((phenyliminoкN)methyl)- $\mu$-phenolato(1-)-кO)copper(II)]; $190 \mathrm{mg}$ (91\%); UV-Vis (MeOH) $\lambda_{\max } / \mathrm{nm}: 237$ and $302\left(\log \varepsilon / \mathrm{dm}^{3} \mathrm{~mol}^{-1} \mathrm{~cm}^{-1}\right.$ : 4.99 and 4.85); IR (KBr), $v_{\max } / \mathrm{cm}^{-1}: 1628(\mathrm{C}=\mathrm{O}), 1619(\mathrm{C}=\mathrm{C})$, $1590(\mathrm{C}=\mathrm{N}), 1291(\mathrm{C}-\mathrm{O}), 599,544(\mathrm{Cu}-\mathrm{O}), 413(\mathrm{Cu}-\mathrm{N})$; Anal. Calcd. mass fractions of elements, $w / \%$, for $\mathrm{C}_{56} \mathrm{H}_{40} \mathrm{Cl}_{2} \mathrm{~N}_{2} \mathrm{O}_{8} \mathrm{Cu}_{2}$ $(\mathrm{Mr}=1066.92)$ are: $\mathrm{C} 63.04, \mathrm{H} 3.78, \mathrm{~N} 2.63$; found: $\mathrm{C} 62.75$, H4.09, N2.79.

Complex 3. [(E)-4-chloro-2-((phenylimino- $k N)$ methyl)phenolato(1-)-kO] (2-phenyl-4-oxo-kO-4H-1-benzopyran-3-olato(1-)-КO)copper(II); $250 \mathrm{mg}$ (94\%); UV-Vis (MeOH) $\lambda_{\max } / \mathrm{nm}$ : 235, 252 and $405\left(\log \varepsilon / \mathrm{dm}^{3} \mathrm{~mol}^{-1} \mathrm{~cm}^{-1}: 4.67,4.62\right.$ and 4.31); IR (KBr), $v_{\text {max }} / \mathrm{cm}^{-1}: 1613(\mathrm{C}=\mathrm{O}), 1590(\mathrm{C}=\mathrm{N}), 1299(\mathrm{C}-\mathrm{O})$, 1355 (C-O), 573, 527, 458 (Cu-O), $420(\mathrm{Cu}-\mathrm{N})$; Anal. Calcd. mass fractions of elements, $w / \%$, for $\mathrm{C}_{56} \mathrm{H}_{40} \mathrm{Cl}_{2} \mathrm{~N}_{2} \mathrm{O}_{8} \mathrm{Cu}_{2}$ $(\mathrm{Mr}=531.45)$ are: $\mathrm{C} 63.28, \mathrm{H} 3.41, \mathrm{~N} 2.64$; found: C62.88, H3.81, N2.79.
Complex 4. [(E)-4-chloro-2-((phenylimino- $k N)$ methyl)phenolato(1-)-kO](2-(4-hydroxy phenyl)-4-oxo-kO-4H-1-benzopyran-3-olato(1-)-kO)copper(II); $200 \mathrm{mg}$ (73\%); UV-Vis (MeOH) $\lambda_{\max } / \mathrm{nm}: 235,258$ and $407\left(\log \varepsilon / \mathrm{dm}^{3} \mathrm{~mol}^{-1} \mathrm{~cm}^{-1}\right.$ : 4.86, 4.78 and 4.54); IR (KBr), $v_{\max } / \mathrm{cm}^{-1}: 1613$ (C=O), 1590 $(\mathrm{C}=\mathrm{N}), 1308$ (C-O), 1355 (C-O), 575, 521, 467 (Cu-O), 416 (Cu-N); Anal. Calcd. mass fractions of elements, $w / \%$, for $\mathrm{C}_{28} \mathrm{H}_{18} \mathrm{ClNO}_{5} \mathrm{Cu}(\mathrm{Mr}=547.44)$ are: $\mathrm{C} 61.43, \mathrm{H} 3.31, \mathrm{~N} 2.56$; found: C61.07, H3.66, N2.73.

\section{X-ray Crystallography}

Data collections were performed at room temperature on an Oxford Diffraction Xcalibur Nova R diffractometer with a microfocusing Cu tube $(\lambda=1.54179 \AA$ A). Data reduction and cell refinement were carried out using the CRYSALIS PRO software. ${ }^{[31]}$ The structures were solved by direct methods with SIR2014 and refined by a full matrix least-squares refinement based on $F^{2}$, with SHELXL. ${ }^{[32,33]}$ Molecular illustrations were prepared with MERCURY included into the WinGX package. ${ }^{[34,35]}$ Calculations of molecular geometries and crystal packing parameters were performed with PLATON. ${ }^{[36]}$ Hydrogen atoms were either included in their geometrically calculated positions and refined according to the riding model, or located in the Fourier map and refined freely.

\section{Catalytic Activity}

The kinetics of DTBC catalytic oxidation by copper(II) complexes $(\mathbf{1}$ - 4) was investigated spectrophotometrically under pseudo first order conditions. All measurements were done in methanol at controlled ambient temperature $25 \pm 1{ }^{\circ} \mathrm{C}$. In a typical experiment the copper(II) complex $\left(1.25 \times 10^{-5} \mathrm{~mol} \mathrm{dm}^{-3} ; 1600 \mu \mathrm{L}\right)$, hydrogen peroxide (30\% $w / w, 25 \mu \mathrm{L})$, DTBC $\left(1 \times 10^{-2} \mathrm{~mol} \mathrm{dm}^{-3} ; 500-25 \mu \mathrm{L}\right)$ and methanol (up to total volume of $2000 \mu \mathrm{L}$ ) were mixed in quartz cuvette. An increase in absorbance at $\lambda_{\max }=400 \mathrm{~nm}$ of the resulting 3,5-di-tert-butylquinone (DTBQ) was followed every 10 seconds during the first 10 minutes of an experiment.

Cyclic voltammetry measurements were conducted in methanol with tetrabuthylammonium hexafluorophosphate $(5 \mathrm{mg} / \mathrm{mL})$ as supporting electrolyte using a three electrode system as described in Physical measurements. Cyclic voltammograms of the mixtures containing copper(II) complex $1-4\left(6.20 \times 10^{-6} \mathrm{~mol} \mathrm{dm}^{-3}\right)$, hydrogen peroxide $\left(0.1 \mathrm{~mol} \mathrm{dm}^{-3}\right)$ and DTBC $\left(2.50 \times 10^{-3} \mathrm{~mol} \mathrm{dm}^{-3}\right)$ were recorded every 5 minutes during 30 minutes. All voltammograms were recorded using $-0.4 \mathrm{~V}$ as first, $+0.6 \mathrm{~V}$ as a second vertex potential and $+0.3 \mathrm{~V}$ as an initial potential at $50 \mathrm{mV} \mathrm{s}^{-1}$ scan rate. Two scans were acquired in each measurement. 


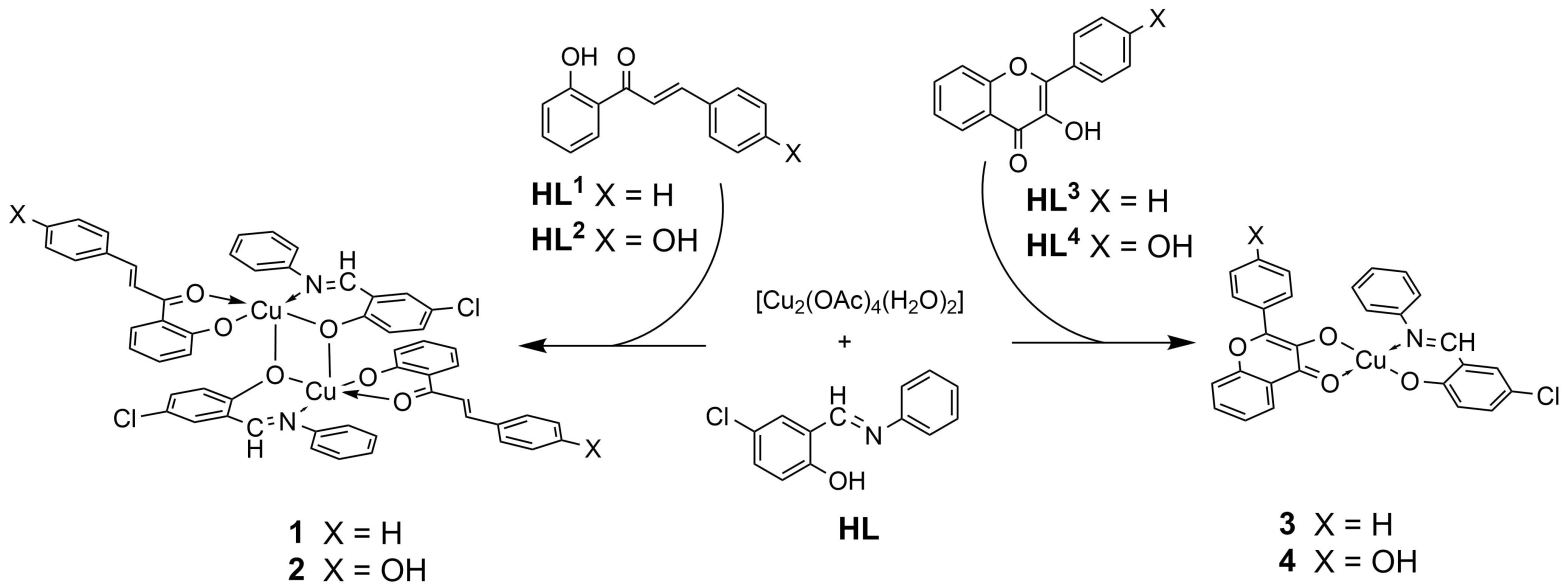

Scheme 1. The synthetic route for complexes $1-4$.

\section{RESULTS AND DISCUSSION}

\section{Syntheses}

Complexes 1 - 4 were prepared by one-step synthetic strategy starting from the binuclear copper(II) acetate dihydrate in the presence of Schiff base and chalcone $\left(H L^{1}\right.$, $\left.\mathrm{HL}^{2}\right)$ or flavonol $\left(\mathrm{HL}^{3}, \mathrm{HL}^{4}\right)$ ligands in molar ratio $1: 2: 2$, respectively. This stoichiometry was supposed to provide the coordination of the bidentate anionic $O, N$ Schiff base and anionic bidentate flavonol or chalcone ligands through carbonyl and deprotonated hydroxyl oxygen atoms.

Copper(II) complexes were characterized by elemental $\mathrm{CHN}$ analyses, infrared and electronic spectroscopy, as well as by cyclic voltammetry along with determination of their crystal and molecular structures by X-ray diffraction.

\section{Molecular and crystal structures}

Crystal data, data collection and refinement parameters are summarized in Table 1.

When the Schiff base, $N$-phenyl-5-chlorosalicylideneimine, is combined with the chalcone derivates, 2'hydroxychalcone and 2',3-dihydroxychalcone, the binuclear complexes $\mathbf{1}$ and $\mathbf{2}$ are formed where two copper ions are embedded in two penta-coordinated square pyramidal coordination spheres sharing one edge $(01-01 i$, Figure 1$)$ and mutually related by an inversion center. The pyramids reveal the Jahn-Teller distortion with the apical donors $01 i$ in 1 and 2 at the distances of 2.5407 (14) $\AA$ and 2.421 (3) $\AA$,

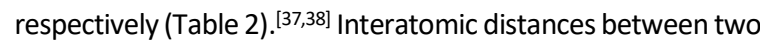
copper atoms are 3.1442 (3) Å in $\mathbf{1}$ and 3.1300 (10) $\AA$ in $\mathbf{2}$.

The flavonol derivatives, 3-hydroxyflavone and 3,3'dihydroxyflavone, combined with the same Schiff base, form mononuclear copper complexes $\mathbf{3}$ and $\mathbf{4}$ where $\mathrm{Cu}$ (II) is tetra-coordinated (by a nitrogen and a deprotonated phenolic oxygen from the Schiff base, as well as by two oxygen donors from the flavonol derivatives) forming, in both cases, almost ideal square planar coordination spheres $(\tau=0.09$ and 0.03 , respectively, the theoretical value for SP being 0.0 ) (Figure 2 and Table 2).

In the packing of 2, the $\mathrm{H}$-bond $\mathrm{O} 4-\mathrm{H} 4 \mathrm{a} \cdots \mathrm{O} 2 \mathrm{ii}[\mathrm{D}-\mathrm{H}$ : 1.22 (8) $\AA, H \cdots A: 1.58(8) \AA, D \cdots A: 2.799$ (6) $\AA, D \cdots A: 173(6)^{\circ}$, symmetry operation on $A: 1-x,-y, 1-z]$ is responsible for the formation of an infinite chain of binuclear complex molecules which progress parallel to the crystallographic $a c$ plane (Figure 3).

\section{Spectroscopic Characterization INFRARED SPECTRA}

Infrared spectra of copper complexes are in accordance with the $\mathrm{CuO}_{3} \mathrm{~N}$ core in $\mathbf{3}$ and $\mathbf{4}$ and two binuclear $\mathrm{CuO}_{4} \mathrm{~N}$ cores in $\mathbf{1}$ and $\mathbf{2}$ (Figures S1 and S2), as confirmed by the Xray structure analysis (vide supra). Schiff base binds metal center via azomethine nitrogen and deprotonated phenolic oxygen. Strong absorptions at $1592 \mathrm{~cm}^{-1}$ for 1 and at 1590 $\mathrm{cm}^{-1}$ for $\mathbf{2}-\mathbf{4}$ are assigned to the azomethine stretching vibration compared to the band at $1613 \mathrm{~cm}^{-1}$ in free ligand. The significant shift toward lower wavenumbers (for $21-23$ $\mathrm{cm}^{-1}$ ) is the proof of the azomethine nitrogen strongly bound to copper. ${ }^{[40]}$ Phenolic $\mathrm{C}-\mathrm{O}(\mathrm{H})$ bond demonstrates a shift from $1274 \mathrm{~cm}^{-1}$ in the free Schiff base to higher frequencies in the corresponding complex, as a result of an electronic density increase on $\mathrm{C}-\mathrm{O}(\mathrm{Cu})$ upon deprotonation. Corresponding bands are found at 1299 and 1308 $\mathrm{cm}^{-1}$ for 3 and 4 , respectively. In the case of binuclear complexes ( $\mathbf{1}$ and $\mathbf{2}$ ) this shift is slightly less significant, as a result of the bridging nature of the phenolic oxygen from the Schiff base. Therefore, C-O stretching appears at 1290 in $\mathbf{1}$, and $1291 \mathrm{~cm}^{-1}$ in $\mathbf{2}$. Coordination of 3-hydroxyflavone to copper via oxygen atoms of the carbonyl and $3-\mathrm{OH}$ group is confirmed in the spectra of $\mathbf{3}$ and $\mathbf{4}$. In the free ligands 
Table 1. Crystallographic data for complexes $1-4$

\begin{tabular}{|c|c|c|c|c|}
\hline Structure & 1 & 2 & 3 & 4 \\
\hline Brutto formula & $\mathrm{C}_{56} \mathrm{H}_{40} \mathrm{Cl}_{2} \mathrm{Cu}_{2} \mathrm{~N}_{2} \mathrm{O}_{6}$ & $\mathrm{C}_{56} \mathrm{H}_{40} \mathrm{Cl}_{2} \mathrm{Cu}_{2} \mathrm{~N}_{2} \mathrm{O}_{8}$ & $\mathrm{C}_{28} \mathrm{H}_{18} \mathrm{ClCuNO}_{4}$ & $\mathrm{C}_{28} \mathrm{H}_{18} \mathrm{ClCuNO}_{5}$ \\
\hline Mol. weight (g mol${ }^{-1}$ ) & 1034.88 & 1066.88 & 531.42 & 547.42 \\
\hline Crystal color and habit & brown needle & brown stick & brown plate & brown needle \\
\hline Crystal dim. (mm) & $0.12 \times 0.02 \times 0.01$ & $0.35 \times 0.12 \times 0.08$ & $0.13 \times 0.07 \times 0.01$ & $0.13 \times 0.02 \times 0.01$ \\
\hline Space group & $\mathrm{C} 2 / \mathrm{c}$ & $P-1$ & $P 2_{1} / c$ & $\mathrm{C} 2 / \mathrm{c}$ \\
\hline$a(\AA)$ & $23.8999(3)$ & $10.5297(8)$ & $12.9233(2)$ & $28.6981(18)$ \\
\hline$b(\AA)$ & $11.4291(2)$ & $11.4986(9)$ & $9.9042(2)$ & $8.4309(4)$ \\
\hline$c(\AA)$ & $17.1650(3)$ & $11.6300(10)$ & $18.7656(3)$ & $18.8949(8)$ \\
\hline$\alpha\left(^{\circ}\right)$ & 90. & $104.372(8)$ & 90. & 90. \\
\hline$\beta\left({ }^{\circ}\right)$ & $93.2500(10)$ & $112.741(8)$ & $107.022(2)$ & $92.716(5)$ \\
\hline$\gamma\left({ }^{\circ}\right)$ & 90. & $102.323(7)$ & 90. & 90. \\
\hline$V\left(\AA^{3}\right)$ & $4681.15(13)$ & $1180.18(18)$ & $2296.68(7)$ & $4566.5(4)$ \\
\hline Z & 4 & 1 & 4 & 8 \\
\hline$\mu\left(\mathrm{Cu} K_{\alpha}\right)\left(\mathrm{mm}^{-1}\right)$ & 2.619 & 2.649 & 2.722 & 2.791 \\
\hline Absorption correction & multi-scan & multi-scan & multi-scan & multi-scan \\
\hline$F(000)$ & 2120 & 546 & 1084 & 2232 \\
\hline$\Theta \max \left({ }^{\circ}\right)$ & 76.52 & 75.75 & 75.67 & 76,14 \\
\hline No. refl. measured & 12506 & 9393 & 11292 & 11507 \\
\hline No. refl. unique & 4855 & 4754 & 4726 & 4714 \\
\hline No. refl. observed $[I>2 \sigma(I)]$ & 4310 & 3622 & 4027 & 4278 \\
\hline$R_{\text {int }}$ & 0.0387 & 0.0958 & 0.0594 & 0.0256 \\
\hline$R_{\sigma}$ & 0.0523 & 0.0866 & 0.0630 & 0.0393 \\
\hline Parameters & 387 & 320 & 316 & 374 \\
\hline$R_{1}[I>2 \sigma(I)]$ & 0.0380 & 0.0888 & 0.0830 & 0.0395 \\
\hline$w R_{2}$, all & 0.1088 & 0.2912 & 0.2545 & 0.1196 \\
\hline S & 1.038 & 1.096 & 1.116 & 1.078 \\
\hline$\rho_{\max }, \rho_{\min }\left(\mathrm{e} \AA^{-3}\right)$ & $028 ;-0.48$ & $1.165 ;-1.487$ & $1.420 ;-0.793$ & $0.45 ;-0.40$ \\
\hline
\end{tabular}

$\left(\mathrm{HL}^{3}\right.$ and $\left.\mathrm{HL}^{4}\right)$ carbonyl group appears at 1627 and $1637 \mathrm{~cm}^{-1}$, respectively, while in $\mathbf{3}$ and $\mathbf{4}$, strong absorptions appear at $1613 \mathrm{~cm}^{-1}$. Coordination of deprotonated 3-OH group to the metal center is confirmed by the shift of the absorptions at 1351 and $1341 \mathrm{~cm}^{-1}$ in the free $\mathrm{HL}^{3}$ and $\mathrm{HL}^{4}$ to 1355 and $1352 \mathrm{~cm}^{-1}$ in spectra of the complexes $\mathbf{3}$ and $\mathbf{4}$, respectively. ${ }^{[41,42]}$

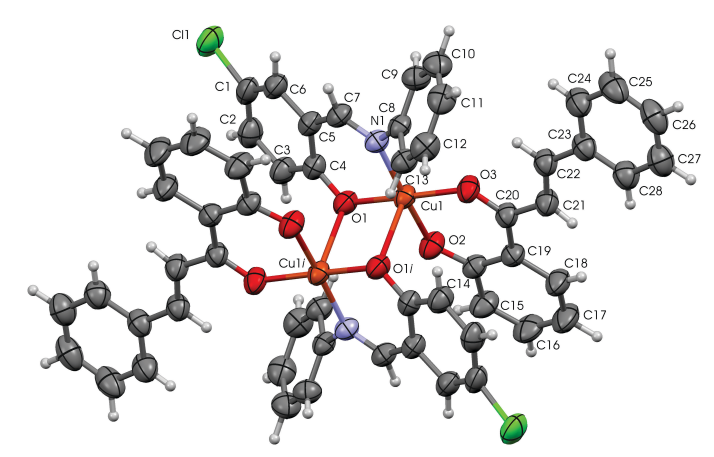

Chalcone ligands are bound to the copper through carbonyl and hydroxyl oxygen atoms. In the free $\mathrm{HL}^{1}$ and $\mathrm{HL}^{2}$ ligands a broad and strong absorption band that covers $\mathrm{C}=\mathrm{O}$ and $\mathrm{C}=\mathrm{C}$ groups appears at 1640 and $1637 \mathrm{~cm}^{-1}$. In the spectra of the complex compounds two separated bands appear at 1627 and $1618 \mathrm{~cm}^{-1}$ (1) and 1628 and $1619 \mathrm{~cm}^{-1}$ (2), ascribed to carbonyl and $\mathrm{C}=\mathrm{C}$ groups, respectively. ${ }^{[43,44]}$

Figure 1. ORTEP of 1 (left) and $\mathbf{2}$ (right).

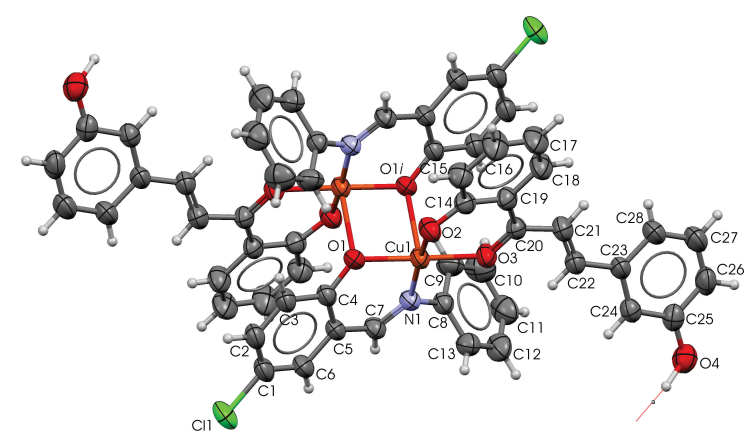


Table 2. Bond lengths $(\AA)$ and bond angles $\left({ }^{\circ}\right)$ within the coordination spheres around copper

\begin{tabular}{|c|c|c|c|c|}
\hline & 1 & 2 & 3 & 4 \\
\hline $\mathrm{Cu}-\mathrm{N}$ & $1.9849(14)$ & $1.976(4)$ & $1.975(3)$ & 1.9731 (17) \\
\hline $\mathrm{Cu}-\mathrm{O} 1$ & $1.9233(13)$ & $1.927(3)$ & $1.869(3)$ & $1.8942(16)$ \\
\hline $\mathrm{Cu}-\mathrm{O} 2$ & $1.8936(13)$ & $1.910(3)$ & $2.004(3)$ & $1.9690(14)$ \\
\hline $\mathrm{Cu}-\mathrm{O} 3$ & $1.9343(14)$ & $1.941(3)$ & $1.899(3)$ & 1.9049 (15) \\
\hline $\mathrm{Cu}-01 i$ & $2.5407(14)^{(a)}$ & $2.421(3)^{(b)}$ & - & - \\
\hline $\mathrm{N}-\mathrm{Cu}-\mathrm{O} 1$ & $92.10(6)$ & 91.91 (14) & $94.53(12)$ & $93.92(7)$ \\
\hline $\mathrm{N}-\mathrm{Cu}-\mathrm{O} 2$ & $174.40(6)$ & $167.80(16)$ & $173.55(12)$ & $177.82(8)$ \\
\hline $\mathrm{N}-\mathrm{Cu}-\mathrm{O} 3$ & $91.07(6)$ & $91.11(14)$ & $95.23(12)$ & $94.40(7)$ \\
\hline $\mathrm{O} 1-\mathrm{Cu}-\mathrm{O} 2$ & $86.06(6)$ & $86.86(14)$ & $86.81(11)$ & $87.04(6)$ \\
\hline $\mathrm{O} 1-\mathrm{Cu}-\mathrm{O} 3$ & $173.61(6)$ & $176.80(13)$ & $169.75(12)$ & $169.57(7)$ \\
\hline $\mathrm{O} 2-\mathrm{Cu}-\mathrm{O} 3$ & $90.26(6)$ & 89.96 (14) & $83.83(11)$ & $84.87(6)$ \\
\hline $\mathrm{N}-\mathrm{Cu}-\mathrm{O} 1 i$ & $97.40(6)$ & $96.01(13)$ & - & - \\
\hline $\mathrm{O} 1-\mathrm{Cu}-\mathrm{O} 1 i$ & $91.57(5)$ & $88.64(12)$ & - & - \\
\hline $\mathrm{O} 2-\mathrm{Cu}-\mathrm{O} 1 i$ & $87.94(5)$ & 96.09 (14) & - & - \\
\hline $\mathrm{O} 3-\mathrm{Cu}-\mathrm{O} 1 i$ & $93.53(6)$ & $92.10(13)$ & - & - \\
\hline$\tau$ descriptor ${ }^{[37,39]}$ & 0.01 (SQP) & 0.15 (SQP) & 0.09 (SP) & $0.03(\mathrm{SP})$ \\
\hline
\end{tabular}

(a) Symmetry operation in 1 on $01 i$ : 1/2-x, 1/2-y, 1-z

(b) Symmetry operation in 2 on $01 i:-x,-y, 1-z$

In spectra of all complexes, several new bands in the low frequency region are attributed to copper-nitrogen bond and different copper-oxygen bonds. ${ }^{[3,45,46]}$ The bridging role of the phenolic oxygen from the Schiff base in $\mathbf{1}$ and $\mathbf{2}$ is a result of the stronger nucleophilicity of the chalcone compared to the flavonol ligands. Therefore $\mathrm{Cu}-\mathrm{O}$ stretching frequencies in $\mathbf{1}$ and $\mathbf{2}$ are found at $608,549 \mathrm{~cm}^{-1}$ and $599,544 \mathrm{~cm}^{-1}$, respectively, while $\mathrm{Cu}-\mathrm{N}$ absorption occurs at $413 \mathrm{~cm}^{-1}$. In the spectra of complexes containing flavonol ligands, $\mathrm{Cu}-\mathrm{O}$ absorptions occur at slightly lower frequencies appearing at 573,527, $458 \mathrm{~cm}^{-1}$ and 575, 521, 467 $\mathrm{cm}^{-1}$, respectively for 3 and 4. Frequencies of $\mathrm{Cu}-\mathrm{N}$ stretching are found at 420 and $416 \mathrm{~cm}^{-1}$.

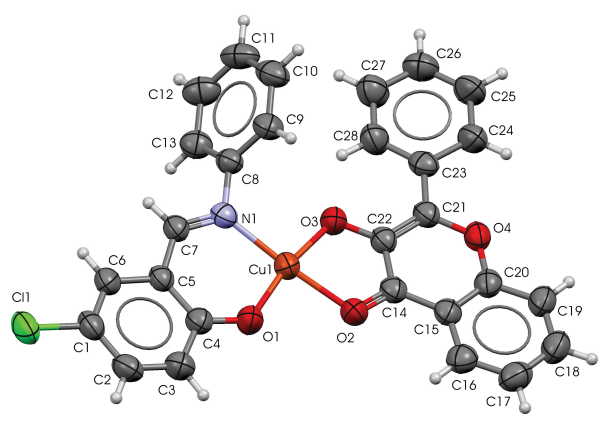

\section{ELECTRONIC SPECTRA}

Electronic spectra of the free ligands and corresponding complexes were recorded in methanol (Figure 4). The general spectral feature of the copper complexes with chalcone ligands ( $\mathbf{1}$ and $\mathbf{2}$ ) refers to a significant blue shift of $n \rightarrow \pi^{*}$ intraligand transitions after chalcone coordination, while the bands corresponding to $n \rightarrow \pi^{*}$ transitions of Schiff base underwent small or negligible changes. In the electronic spectra of the Schiff bases, three intraligand band originating from $\pi \rightarrow \pi^{*}$ and $n \rightarrow \pi^{*}$ transitions appear at 231,267 and $350 \mathrm{~nm} \cdot{ }^{[40,47]}$ In the spectrum of 1, two intraligand transition bands at 240 and $306 \mathrm{~nm}$ were found. A very broad band at $306 \mathrm{~nm}$ is

Figure 2. ORTEP of $\mathbf{3}$ (left) and $\mathbf{4}$ (right).

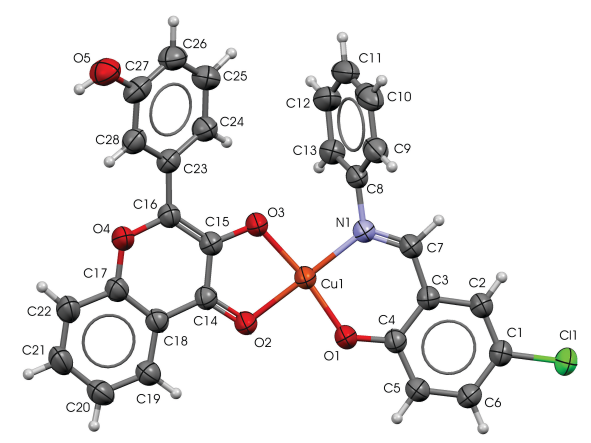

Croat. Chem. Acta 2018, 91(2), 195-207

DOI: $10.5562 /$ cca3334 


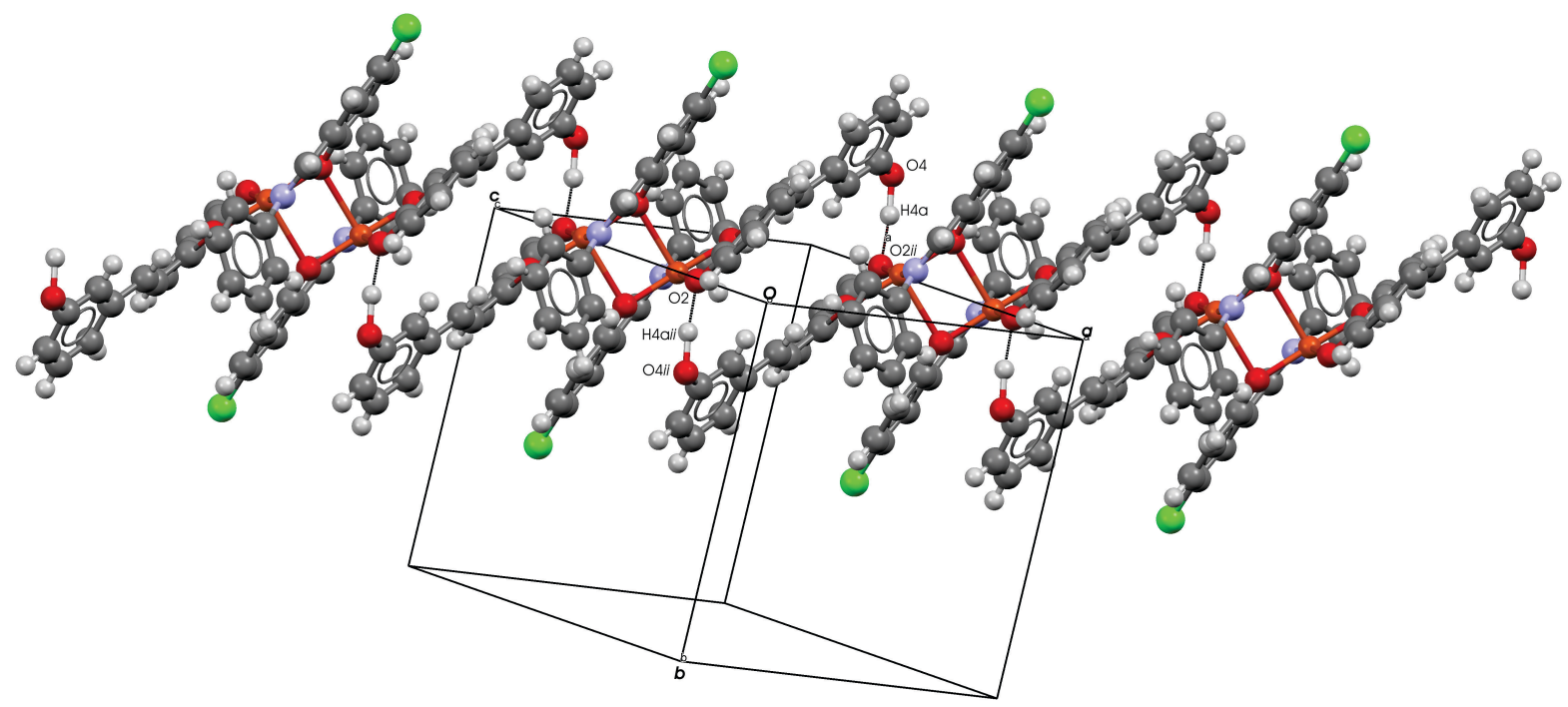

Figure 3. Packing of 2 in crystal structure.

ascribed to the superimposed $n \rightarrow \pi^{*}$ transitions of both, Schiff base and chalcone ligands. Significant hypsochromic (blue) shift $(\Delta \lambda=12 \mathrm{~nm})$ compared to the spectrum of the free chalcone $\left(\lambda_{\max }=318 \mathrm{~nm}\right)$ corresponds to strong involvement of carbonyl group in the coordination. ${ }^{[27,43,44,48]}$ The MLCT band appears at $400 \mathrm{~nm}$.

In the spectrum of 2 all intraligand transition bands are found. Schiff bases absorptions underwent negligible shift while absorption at $306 \mathrm{~nm}$, which is found at $313 \mathrm{~nm}$ in free $\mathrm{HL}^{2}$, confirm strong binding of 2',3-dihydroxychalcone. A new band at $427 \mathrm{~cm}$ is recognized as the MLCT band, based on its position and molar extinction coefficient.

The main features of the electronic spectra of copper(II) flavonol complexes are two LMCT bands in the visible region and two strong intensity bands in the ultraviolet region along with several shoulders in 330-270 $\mathrm{nm}$ region (Figure 4). Bands appearing in the spectra of complexes (3 and $\mathbf{4}$ ) at 238 are attributed to $\pi \rightarrow \pi^{*}$ transition of both ligands. On the other hand, band at 253 $\mathrm{nm}$ can be attributed only to intraligand transition of Schiff base and compared to the spectrum of the free ligand it is blue-shifted for almost $20 \mathrm{~nm}$ thus confirming strong binding of Schiff base to copper(II). Several shoulders appearing in the spectra of the complexes 3 and $\mathbf{4}$ in $330-$ 270 region arise from $n \rightarrow \pi^{*}$ transitions of the coordinated Schiff base and flavonol and are blue-shifted compared to the corresponding transitions in the spectra of the free ligands. ${ }^{[41,42]}$

\section{Electrochemical Characterization}

Electrochemical properties of the metal complexes are significant for the catecholase activity. The redox activity of

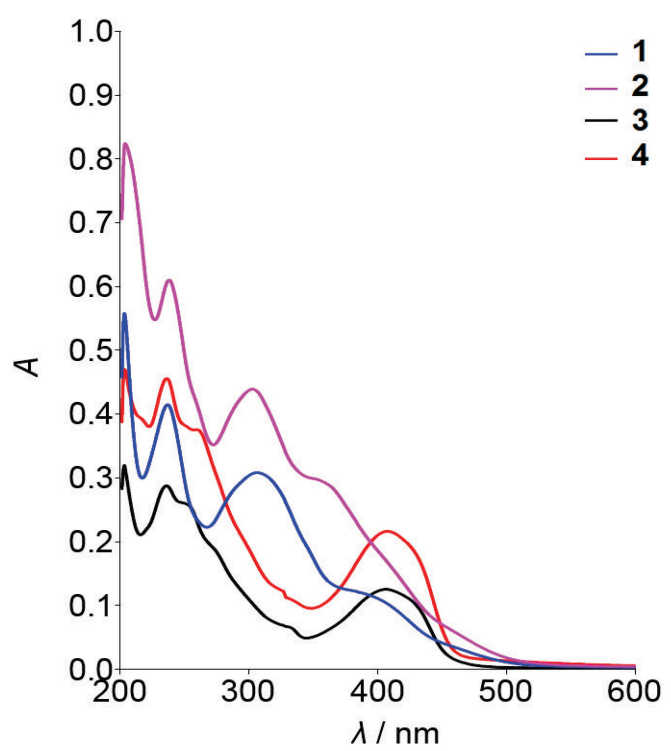

Figure 4. Electronic absorption spectra of the complexes $1-4\left(6.25 \times 10^{-6} \mathrm{~mol} \mathrm{dm}^{-3}\right)$ in methanol.

copper in most enzymes is based on its ability to switch between its two most common oxidation states which basically depends on the hard-soft character of the donor atoms from the ligands and the geometry of the copper sites. Ligands with soft donor atoms like sulfur and nitrogen increase redox potential by facilitating the reduction of $\mathrm{Cu}(\mathrm{II})$ to $\mathrm{Cu}(\mathrm{I})$. The effect of the coordination sphere geometry on the redox potential is influenced by distortion of tetragonal coordination, which is characteristic of $\mathrm{Cu}(\mathrm{II})$ complexes, towards tetrahedral geometry, which is typical of $\mathrm{Cu}(\mathrm{I})$ complexes. It is no wonder, therefore, that in many 

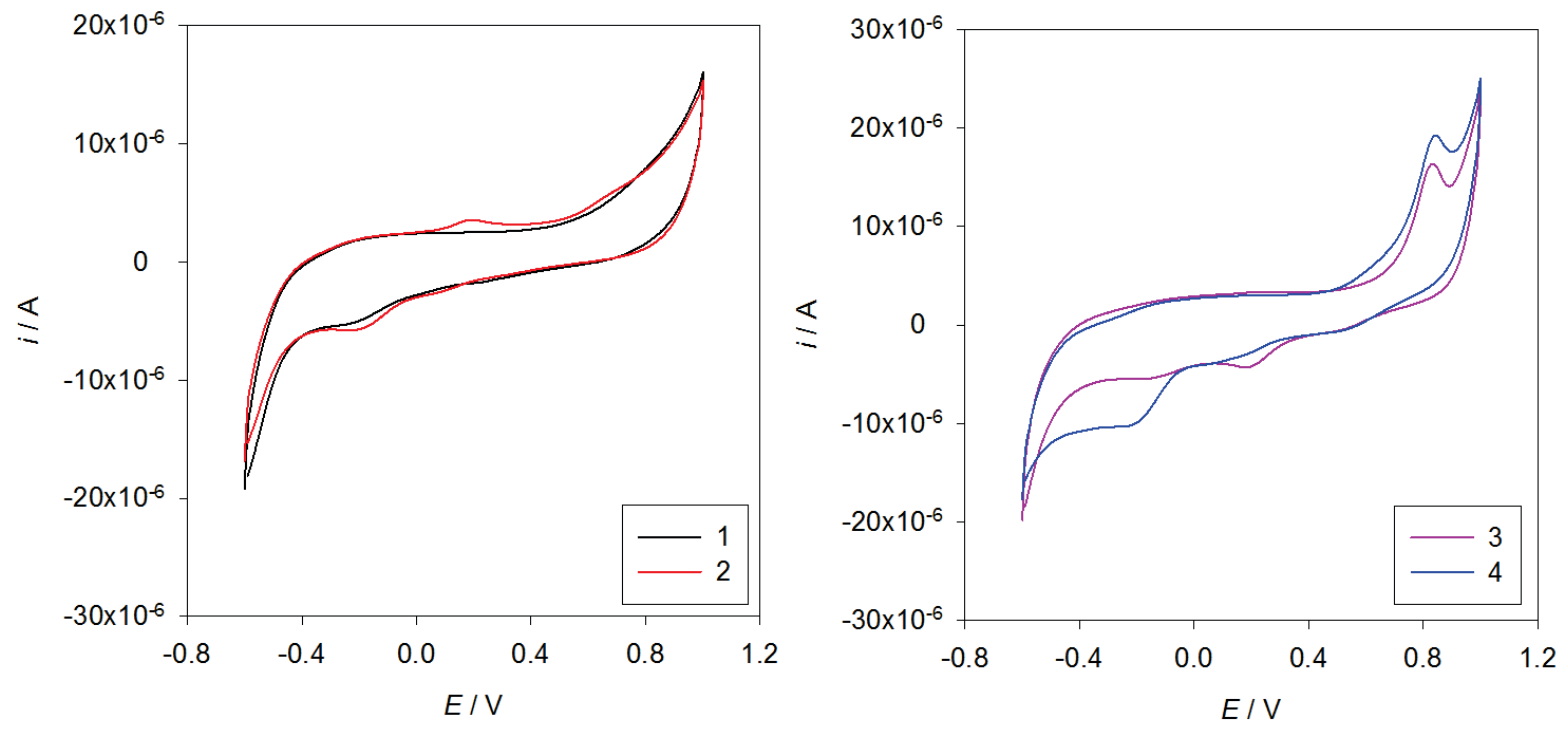

Figure 5. Cyclic voltammograms of the complexes $1-4\left(2 \times 10^{-4} \mathrm{~mol} \mathrm{dm}^{-3}\right)$ in DMSO. Supporting electrolyte $50 \mathrm{mM} \mathrm{Bu}_{4} \mathrm{NPF}_{6}$, scan rate $100 \mathrm{mV} \mathrm{s}^{-1}$.

copper-containing enzymes rather distorted coordination spheres are found, which can be described as a geometric compromise between the tetragonal and tetrahedral extremes. ${ }^{[45]}$ The early reports on the potentials of $\mathrm{Cu}(\mathrm{II}) / \mathrm{Cu}(\mathrm{I})$ couple in the different copper proteins refer to a very wide potential range between 183 and $785 \mathrm{mV} .{ }^{[49,50]}$

Cyclic voltammograms of the complexes $1-4$ revealed several quasi-reversible redox processes (Figure 5). The most obvious feature of the voltammograms are well defined cathodic peaks in the potential range -0.12 to $-0.20 \mathrm{~V}$, corresponding to $\mathrm{Cu}(\mathrm{II})$ reduction (Table S1). Negative potential values are in accordance with $\mathrm{CuO}_{3} \mathrm{~N}$ and $\mathrm{CuO}_{4} \mathrm{~N}$ coordination cores and respectable stabilization of +2 oxidation state. Chalcone ligands were shown to be redox inactive in this potential range, while flavonols $\left(\mathrm{HL}^{3}\right.$ and $\mathrm{HL}^{4}$ ) exhibited quasi-reversible oxidation of 3-hydroxyl moiety at potential near $+0.8 \mathrm{~V}$ (Figure S11). In complexes 3 and 4, this oxidation wave is shifted towards more positive values $\left(\Delta E_{\mathrm{p}, \mathrm{a}} \sim+30 \mathrm{mV}\right.$ ) having lower reversibility $\left(\Delta E_{\mathrm{p}} \sim 300 \mathrm{mn}\right.$ ), as compared to $\sim 160 \mathrm{mV}$ in voltammograms of the free ligand, suggesting hardened oxidation as a consequence of the coordination to $\mathrm{Cu}$ (II) (Table S1).

\section{Catalytic Activity}

Many simple inorganic copper(II) complexes reveal intriguing biomimetic catecholase-like activity (Scheme 2). ${ }^{[51-56]}$ Although native catecholase isolated from plants contain binuclear copper(II) sites, many complexes of different nuclearity are the subject of the research, basically from the kinetic and mechanistic aspects. ${ }^{[11,46,54,55,57]}$ Many reports refer to the superior activity of the binuclear $\mathrm{Cu}$ (II) sites and role of the $\mathrm{Cu}-\mathrm{Cu}$ distance in the activation of a<smiles>CC(C)(C)c1cc(O)c(O)c(C(C)(C)C)c1</smiles>

Scheme 2. Catalytic oxidation of DTBC to DTBQ.

small dioxygen molecule.[46] Since copper(II) Schiff base complexes with flavonol and chalcone ligands, $\mathbf{1 - 4}$, meet some criteria for the catalytic oxidation of catechol, their catalytic activities were tested by spectroscopic and electrochemical measurements. In all experiments DTBC was used as a substrate due to its low oxidation potential and absence of any concomitant or successive reaction upon its oxidation to DTBQ.

\section{Spectroscopic Evidence of the Catalysis}

Catalytic activities of the copper complexes $\mathbf{1}-\mathbf{4}$ were tested spectrophotometrically by monitoring an absorbance increase at the band corresponding to quinone (DTBQ) formation $\left(\lambda_{\max }=400 \mathrm{~nm} ; \varepsilon=1600 \mathrm{~mol}^{-1} \mathrm{dm}^{3} \mathrm{~cm}^{-1}\right)$. ${ }^{[57]}$

Catalytic reaction mixtures containing complexes 1 4, DTBC and hydrogen peroxide as co-oxidant showed significant absorbance increase at $400 \mathrm{~nm}$ (Figure 6 and Figures S5, S6). In the absence of $\mathrm{Cu}(\mathrm{II})$ complexes no obvious change in the spectrum of DTBC was observed, which confirms utterly catalytic nature of this oxidation process (Figure S10). In the time-dependent electronic spectra of the catalytic system, a brand new band near 360 $\mathrm{nm}$ (Figure 7) appears. Based on its position and intensity progressing over time (considerably slower than the 


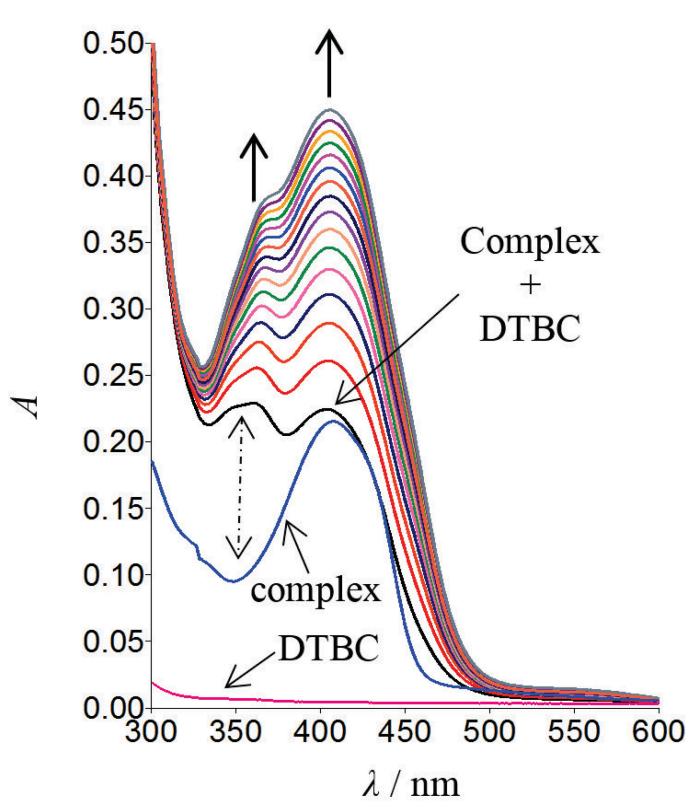

Figure 6. Changes in the absorption spectra in the course of catalytic oxidation of DTBC $\left(2.56 \times 10^{-3} \mathrm{~mol} \mathrm{dm}^{-3}\right)$ by complex $4\left(6.28 \times 10^{-6} \mathrm{~mol} \mathrm{dm}^{-3}\right)$ in the presence of hydrogen peroxide $\left(0.12 \mathrm{~mol} \mathrm{dm}^{-3}\right)$ in methanol at room temperature during 10 minutes. intensity of the DTBQ band) along with the absence of any band whatsoever at $650-700 \mathrm{~nm}{ }^{[56]}$, this absorption can be ascribed to the formation of $\mathrm{Cu}(\mathrm{II})$-catecholate intermediate. This is in accordance with the strong affinity of catechol to $\mathrm{Cu}(\mathrm{II})$ center in complexes $\mathbf{1}-\mathbf{4}$ (vide infra $K_{\mathrm{M}}$ ).

Complexes $\mathbf{1}-\mathbf{4}$ revealed remarkable stability in methanol solutions for more than six months and their catalytic activity can be addressed to the originally formulated complex species.

\section{Kinetic Measurements}

In order to assess catalytic performances of complexes $1-\mathbf{4}$, kinetic measurements were conducted at pseudofirst reaction order conditions using initial rate method. An initial reaction rates were determined keeping the concentration of the co-oxidant and $\mathrm{Cu}(\mathrm{II})$ complexes constant while varying the concentrations of DTBC (Figure S7). Results showed that the catalytic reactions obey MichaelisMenten kinetics and catalytic parameters could be calculated from Lineweaver-Burk plot (Figure 7 and S8,S9).

Catalytic parameters, maximum reaction rate $\left(v_{\max }\right)$, Michaelis-Menten constant $\left(K_{\mathrm{M}}\right)$, catalytic efficiency, catalytic reaction rate constant $\left(k_{\text {cat }}\right)$, turn over number (TON) and turn over frequencies (TOF) for complexes $1-4$ in DTBC oxidation are summarized in Table 3.
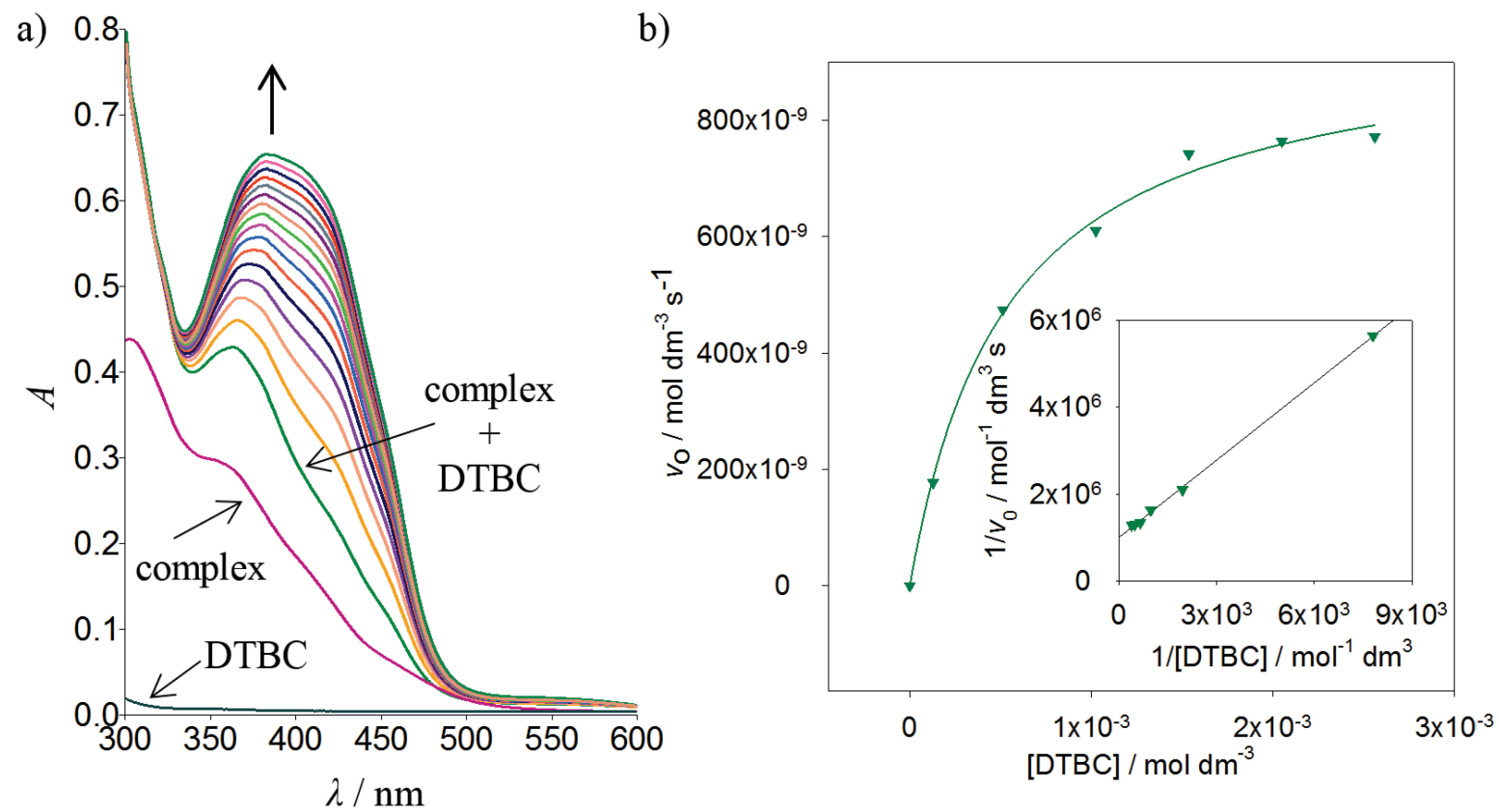

Figure 7. a) Changes in the absorption spectra in the course of catalytic oxidation of DTBC $\left(2.56 \times 10^{-3} \mathrm{~mol} \mathrm{dm}^{-3}\right)$ by complex 2 $\left(6.28 \times 10^{-6} \mathrm{~mol} \mathrm{dm}^{-3}\right)$ in the presence of hydrogen peroxide $\left(0.12 \mathrm{~mol} \mathrm{dm}^{-3}\right)$ in methanol $(2 \mathrm{~mL})$ at room temperature during 10 minutes; b) Michaelis-Menten saturation curve: Dependence of the initial rate of oxidation vs DTBC concentration in the presence of the complex 2. Inset: Lineweaver-Burk plot. 
Table 3. Catalytic parameters of complexes $1-4$ for DTBC oxidation

\begin{tabular}{ccccccc}
\hline Complex & $v_{\max } / 10^{-7} \mathrm{~mol} \mathrm{dm}^{-3} \mathrm{~s}^{-1}$ & $K_{\mathrm{M}} / 10^{-3} \mathrm{~mol} \mathrm{dm}^{-3}$ & Efficiency $/ \mathrm{mol}^{-1} \mathrm{dm}^{-3} \mathrm{~s}^{-1}$ & $k_{\text {cat }} / \mathrm{h}^{-1}$ & TON & TOF $/ 10^{-2} \mathrm{~s}^{-1}$ \\
\hline 1 & 12.9 & 1.37 & 152 & 752 & 46.7 & 7.79 \\
2 & 9.86 & 0.58 & 269 & 565 & 50.1 & 8.34 \\
3 & 5.76 & 1.45 & 64 & 332 & 30.2 & 5.03 \\
4 & 5.24 & 0.90 & 94 & 302 & 34.5 & 5.75 \\
\hline
\end{tabular}

Table 4. Comparison of complexes 1 - 4 with some reported catecholase-like biomimetic copper complexes

\begin{tabular}{|c|c|c|c|}
\hline & Complex & $k_{\text {cat }} / h^{-1}$ & Ref. \\
\hline \multirow{7}{*}{ 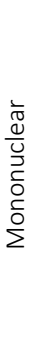 } & {$\left[\mathrm{Cu}(\right.$ phen $\left.)\left(\mathrm{OH}_{2}\right)_{2}\left(\mathrm{NO}_{3}\right)\right]\left(\mathrm{NO}_{3}\right)$} & $3.91 \times 10^{3}$ & [55] \\
\hline & $\mathrm{CuL}\left(\mathrm{NO}_{3}\right)_{2}$ & 3 & [54] \\
\hline & $\mathrm{CuLI}_{2}$ & 64 & [53] \\
\hline & {$\left[\mathrm{Cu}\left(3^{\prime} \mathrm{MePyOIND}\right)_{2}\right]$} & 21 & {$[58]$} \\
\hline & $\mathrm{Cu}(\mathrm{EDTB})\left(\mathrm{NO}_{3}\right)_{2}$ & 3 & {$[11]$} \\
\hline & 3 & 332 & This work \\
\hline & 4 & 302 & This work \\
\hline \multirow{7}{*}{$\begin{array}{l}\frac{1}{\mathbb{d}} \\
\frac{\mathbb{U}}{\mathrm{U}} \\
\frac{.}{\overline{0}}\end{array}$} & {$\left[\mathrm{Cu}_{2}\left(\mathrm{H}_{2} \mathrm{~L}-\left(\mathrm{CH}_{3}\right)_{11}\right)(\mathrm{OH})\left(\mathrm{H}_{2} \mathrm{O}\right)\left(\mathrm{NO}_{3}\right)\right]^{3+}$} & $3.24 \times 10^{4}$ & {$[52]$} \\
\hline & $\mathrm{Cu}_{2} \mathrm{~L}_{2}$ & 720 & {$[51]$} \\
\hline & {$\left[\mathrm{Cu}_{2}\left(\mathrm{LOCH}_{3}\right)(\mu \mathrm{OH})\right]\left[\left(\mathrm{ClO}_{4}\right)_{2}\right]$} & 21 & [59] \\
\hline & {$\left[\mathrm{Cu}_{2}(\mathrm{salam})_{2}\left(\mathrm{NO}_{3}\right)_{2}\right]$} & 28 & {$[60]$} \\
\hline & {$\left[\mathrm{Cu}_{2}(\mathrm{diep})\left(\mathrm{H}_{2} \mathrm{O}\right)_{4}\right]\left(\mathrm{ClO}_{4}\right)_{4}$} & 63 & {$[12]$} \\
\hline & 1 & 752 & This work \\
\hline & 2 & 565 & This work \\
\hline
\end{tabular}

Binuclear copper complexes $\mathbf{1}$ and $\mathbf{2}$ showed better catalytic performances in DTBC oxidation than the mononuclear $\mathrm{CU}$ (II) flavonol-containing complexes $\mathbf{3}$ and $\mathbf{4}$, as expected based on the presence of two active sites per catalyst molecule. Complexes $\mathbf{2}$ and $\mathbf{4}$, having an additional hydroxyl group as compared to their $\mathbf{1}$ and $\mathbf{3}$ analogues, displayed higher affinity for DTBC binding. However, in all cases affinity for the catechol binding is comparable to the one reported for catecholases isolated from plants. ${ }^{[57]}$

Catalytic reaction constant rates $\left(k_{\text {cat }}\right)$ are most commonly used to compare catalyst performances of biomimetic complexes. Complexes $1-4$ have $k_{\text {cat }}$ values of $10^{2} \mathrm{~h}^{-1}$ magnitude and hence can be categorized amongst the best examples in $\mathrm{Cu}(\mathrm{II})$ biomimetic complexes with catecholaselike activity. Even compared to the best known biomimetic $\mathrm{Cu}(\mathrm{II})$ complex $k_{\text {cat }}$ is only 40 times less (Table 4). ${ }^{[52]}$

Since $k_{\text {cat }}$ rather refers to the breakdown of the destined substrate-complex adduct, TON values (turn over number) along with the efficiency of catalysts were calculated. TON values in the case of $\mathbf{1 - 4}$ are given as the ratio of the DTBQ and complex concentration at the defined time $(10 \mathrm{~min})$ taking into account that the conversion is not high (in all cases $<15 \%$ ). The efficiency is given as a ratio of $k_{\text {cat }}$ to $K_{\mathrm{M}}$ (Table 3). TON values for the binuclear complexes $\mathbf{1}$ and $\mathbf{2}$ are higher as compared with the mononuclear flavonol-containing copper complexes $\mathbf{3}$ and 4 . If $k_{\text {cat }}$ values are compared with TON for complexes with the same type of the ligand ( $\mathbf{1}$ and $\mathbf{2}$ or $\mathbf{3}$ and $\mathbf{4}$ ) it becomes clear that $k_{\text {cat }}$ values are not responsible for overall catalytic process. Although the $k_{\text {cat }}$ value for $\mathbf{1}$ is higher than for 2 , higher TON value suggests that 2 is the more promising catalyst due to higher conversion rate of DTBC to DTBQ for $1 \%$ as compared to complex 1 . Catalytic activity is directly related to the number of the catalyst active sites and better activity is found for the complexes of higher nuclearity. ${ }^{[57]}$ In our case, higher activity can be ascribed to the binuclearity, lower stabilization of $\mathrm{Cu}(\mathrm{I})$ (vide infra) and easier release of the product $\left(k_{\text {cat }}\right)$ from the destined substrate-complex adduct in the case of $\mathbf{1}$ and $\mathbf{2}$.

\section{Electrochemical Evidence of Catalysis}

Since the investigation of the catecholase-like activity refers to the redox active process involving a redox active substrate and metal center, electrochemistry provides a valuable tool for confirmation of the catalytic nature of the catechol oxidation as well as for postulating possible mechanisms involved. All electrochemical experiments were conducted under the same experimental conditions as the catalytic experiments followed by the spectrophotometry.

Cyclic voltammograms of the complexes did not show any observable peaks at the concentrations used for the catalytic experiments (Figure S13). DTBC showed one oxidation peak at $+0.27 \mathrm{~V}$ and two reduction peaks at +0.12 $\mathrm{V}$ and $-0.24 \mathrm{~V}$ (Figure S12). The latter one corresponds to the reduction of DTBQ and corresponding current intensity is directly proportional to its concentration. Cyclic voltammograms of the catalytic reaction mixtures (Figure 8 and S15) showed time dependent increase of the current at the peak corresponding to the DTBQ reduction indicating that the concentration of DTBQ increases as the catalytic reaction progresses. This peak is shifted to slightly lower potential value $(-0.30 \mathrm{~V})$ compared to the pure DTBC indicating deprotonation of the substrate upon coordination to $\mathrm{Cu}(\mathrm{II})$ site. 


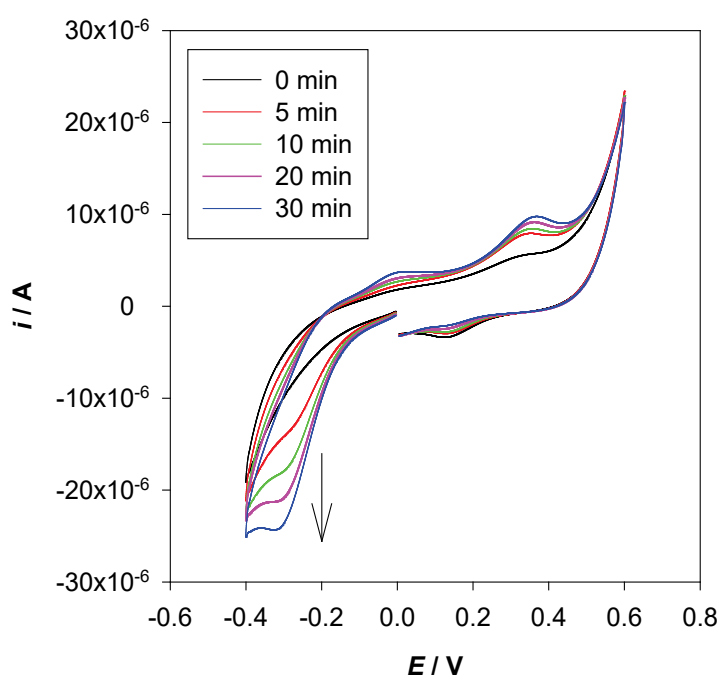

Figure 8. Cyclic voltammograms of the mixture in the course of the catalytic oxidation of DTBC $\left(2.56 \times 10^{-3} \mathrm{~mol} \mathrm{dm}^{-3}\right)$ by complex $3\left(6.28 \times 10^{-6} \mathrm{~mol} \mathrm{dm}^{-3}\right)$ in the presence of hydrogen peroxide $\left(0.12 \mathrm{~mol} \mathrm{dm}^{-3}\right)$ in methanol at room temperature. Supporting electrolyte $5 \mathrm{mg} \mathrm{mL}^{-1} \mathrm{Bu}_{4} \mathrm{NPF}_{6}$, scan rate $100 \mathrm{mV} \mathrm{s}^{-1}$.
In the case of the flavonol-containing copper(II) complexes ( $\mathbf{3}$ and $\mathbf{4}$ ) an additional oxidation peak close to 0 $\mathrm{V}$, corresponding to the oxidation of the semiquinone radical anion (DTBSQ) was observed. ${ }^{[56,61]}$ Lower $k_{\text {cat }}$ values for $\mathbf{3}$ and $\mathbf{4}$ correlate with DTBSQ stabilization as a consequence of the postponed quinone release from $\mathrm{Cu}(\mathrm{I})$.

Based on our results and some mechanistic insights in the catechol oxidation involving similar copper(II) complexes, possible reaction pathway of the DTBC oxidation is illustrated in Scheme 3. Active copper(II) center binds catecholate and oxidizes it to the quinone with concomitant reduction of $\mathrm{Cu}(\mathrm{II})$ to $\mathrm{Cu}(\mathrm{I})$. Reoxidation of $\mathrm{Cu}(\mathrm{I})$ to $\mathrm{Cu}(\mathrm{II})$ is achieved by hydrogen peroxide as co-oxidant which closes the catalytic cycle.

\section{CONCLUSION}

Four new heteroleptic neutral copper(II) complexes were prepared by the solution synthesis from copper(II) acetate, Schiff base $\mathrm{N}$-phenyl-5-salicylideneimine and appropriate flavonol or chalcone ligands. Crystal structures revealed that the copper(II) flavonol complexes are mononuclear, having $\mathrm{CU}$ (II) coordinated by a monobasic Schiff base and a flavonolato ligand, both in the bidentate fashion, with the

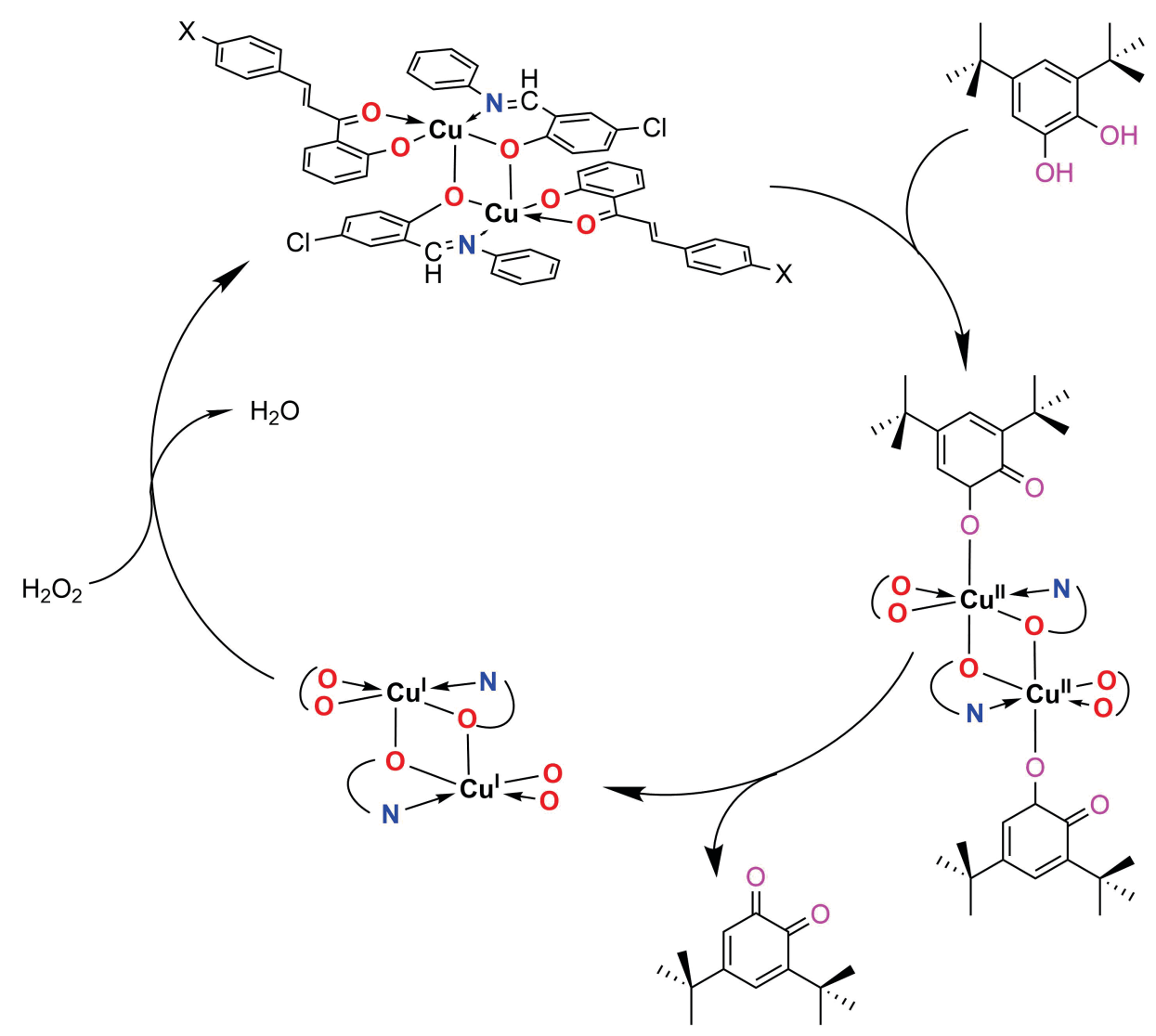

Scheme 3. Possible reaction pathway for DTBC oxidation in the presence of complexes 1 and 2 . 
four donor atoms being disposed in a square planar arrangement. Chalcone copper(II) complexes are binuclear, having two penta-coordinated copper ions embedded in two square pyramidal coordination cores with phenolate oxygen from the Schiff base as a bridging atom. Interatomic distances between the two copper atoms in $\mathbf{3}$ and $\mathbf{4}$ are 3.13 and $3.14 \AA$, respectively. The elemental analysis, infrared and electron spectroscopy data for all complexes are consistent with the results of the X-ray single crystal studies. Electrochemical properties of $\mathrm{Cu}(\mathrm{II})$ complexes are in accordance with $\mathrm{CuO}_{3} \mathrm{~N}$ (flavonol-containing complexes) and $\mathrm{CuO}_{4} \mathrm{~N}$ coordination (chalcon-containing complexes). Electronic absorption spectroscopy and cyclic voltammetry provided evidences for the biomimetic catecholase-like activity of the copper(II) complexes in DTBC oxidation. Binuclear copper complexes have enhanced catalytic activity as compared to the mononuclear $\mathrm{Cu}(\mathrm{II})$ flavonolato complexes. Higher activity of binuclear species can be ascribed to the lower stabilization of $\mathrm{Cu}(\mathrm{I})$ and easier release of the product from the destined substrate-complex adduct.

Supplementary Information. CCDC 1826240-1826243 contain the supplementary crystallographic data. These data can be obtained via http://www.ccdc.cam.ac.uk/conts/retrieving.html (free of charge), or from the Cambridge Crystallographic Data Centre, 12 Union Road, Cambridge CB2 1EZ, UK; fax:(+44) 1223-336-033; or e-mail: deposit@ccdc.cam.ac.uk. Additional data on the characterization of the complexes and catalytic experiments are attached to the electronic version of the article at: http://doi.org/10.5562/cca3334.

\section{REFERENCES}

[1] M. Zhao, H. B. Wang, L. N. Ji, Z. W. Mao, Chem. Soc. Rev. 2013, 42, 8360.

[2] E. I. Solomon, D. E. Heppner, E. M. Johnston, J. W. Ginsbach, J. Cirera, M. Qayyum, M. T. KieberEmmons, C.H. Kjaergaard, R.G. Hadt, L. Tian, Chem. Rev. 2014, 114, 3659.

[3] H. Pracejus, Adv. Synth. Catal. 1975, 317, 350.

[4] I. A. Koval, P. Gamez, C. Belle, K. Selmeczi, J. Reedijk, Chem. Soc. Rev. 2006, 35, 814.

[5] C. Eicken, B. Krebs, J. C. Sacchettini, Curr. Opin. Struct. Biol. 1999, 9, 677.

[6] T. Klabunde, C. Eicken, J.C. Sacchettini, B. Krebs, Nat. Struct. Mol. Biol. 1998, 5, 1084.

[7] A. Rompel, H. Fischer, D. Meiwes, K. BüldtKarentzopoulos, R. Dillinger, F. Tuczek, H. Witzel, B. Krebs, J. Biol. Inorg. Chem. 1999, 4, 56.

[8] A. Neves, L. M. Rossi, A. J. Bortoluzzi, B. Szpoganicz, C. Wiezbicki, E. Schwingel, W. Haase, S. Ostrovsky, Inorg. Chem. 2002, 41, 1788.
[9] N. Oishi, Y. Nishida, K. Ida, S. Kida, Bull. Chem. Soc. Jpn. 1980, 53, 2847.

[10] G. Grigoropoulou, K. C. Christoforidis, M. Louloudi, Y. Deligiannakis, Langmuir 2007, 23, 10407.

[11] Z. F. Chen, Z. R. Liao, D. F. Li, W. K. Li, X. G. Meng, J. Inorg. Biochem. 2004, 98, 1315.

[12] M. R. Mendoza-Quijano, G. Ferrer-Sueta, M. FloresÁlamo, N. Aliaga-Alcalde, V. Gómez-Vidales, V. M. Ugalde-Saldívar, L. Gasque, Dalton Trans. 2012, 41, 4985.

[13] S. Kumar, D. N. Dhar, P. Saxena, J. Sci. Ind. Res. 2009, 68, 181.

[14] K. Gupta, A. K. Sutar, Coord. Chem. Rev. 2008, 252, 1420.

[15] E. Kahrović, A. Zahirović, S. Kraljević Pavelić, E. Turkušić, A. Harej, J. Coord. Chem. 2017, 70, 1683.

[16] E. Kahrović, A. Zahirović, E. Turkušić, S. Bektaš, Z. Anorg. Allg. Chem. 2016, 642, 480.

[17] S. Deshpande, D. Srinivas, P. Ratnasamy, J. Catal. 1999, 188, 261.

[18] C. R. Jacob, S. P. Varkey, P. Ratnasamy, Microporous Mesoporous Mater. 1998, 22, 465.

[19] M. Salavati-Niasari, M. Shakouri-Arani, F. Davar, Microporous Mesoporous Mater. 2008, 116, 77.

[20] S. Kumari, A. K. Mahato, A. Maurya, V. K. Singh, N. Kesharwani, P. Kachhap, I. O. Koshevoy, C. Haldar, New J. Chem. 2017, 41, 13625.

[21] B. Dutta, S. Jana, R. Bera, P. K. Saha, S. Koner, App. Cat. A 2007, 318, 89.

[22] P. Roy, M. Nandi, M. Manassero, M. Riccó, M. Mazzani, A. Bhaumik, P. Banerjee, Dalton Trans. 2009, 43, 9543.

[23] A. Routaray, N. Nath, T. Maharana, P. K. Sahoo, J. P. Das, A. K. Sutar, J. Chem. Sci. 2016, 128, 883.

[24] N. Beyazit, B. Çatıkkaş, Ş. Bayraktar, C. Demetgül, J. Mol. Struct. 2016, 1119, 124.

[25] P. Bhowmik, L. K. Das, S. Chattopadhyay, A. Ghosh, Inorg. Chim. Acta 2015, 430, 24.

[26] F. Amrani, L. Perelló, J. Borrás, L. Torres, Met. Based Drugs 2000, 7, 365.

[27] P. Rachmale, Int. J. Pharm. Sci. Res. 2012, 3, 901.

[28] R. F. De Souza, E. M. Sussuchi, W. F. De Giovani, Synth. React. Inorg. Met. Org. Chem. 2003, 33, 1125.

[29] A. Kurzwernhart, W. Kandioller, S. Bächler, C. Bartel, S. Martic, M. Buczkowska, G. Mühlgassner, M. A. Jakupec, H. B. Kraatz, P. J. Bednarski, J. Med. Chem. 2012, 55, 10512.

[30] A. Zahirović, E. Kahrović, M. Cindrić, S. Kraljević Pavelić, M. Hukić, A. Harej, E. Turkušić, J. Coord. Chem. 2017, 70, 4030.

[31] CrysAlis CCD, Oxford Diffraction Ltd., Version 1.171.32.29 (release 10-02008 CrysAlis171.NET). 
[32] M. C. Burla, R. Caliandro, B. Carrozzini, G. L. Cascarano, C. Cuocci, C. Giacovazzo, M. Mallamo, A. Mazzone, G. Polidori, J. Appl. Crystallogr. 2015, 48, 306.

[33] G. M. Sheldrick, SHELX97: Program for the Refinement of Crystal Structures, Universität Göttingen, Germany, 1997.

[34] L. J. Farrugia, J. Appl. Crystallogr. 1999, 32, 837.

[35] C. F. Macrae, I. J. Bruno, J. A. Chisholm, P. R. Edgington, P. McCabe, E. Pidcock, L. Rodriguez-Monge, R. Taylor, J. V. Streek, P. A. Wood, J. Appl. Crystallogr. 2008, 41, 466.

[36] A. L. Spek, Acta Crystallogr. Sec. C 2015, 71, 9.

[37] A. W. Addison, T. N. Rao, J. Reedijk, J. van Rijn, G. C. Verschoor, J. Chem. Soc., Dalton Trans. 1984, 0, 1349.

[38] M. Bacci, Chem. Phys. 1986, 104, 191.

[39] L. Yang, D. R. Powell, R. P. Houser, Dalton Trans. 2007, 9, 955.

[40] J. Kovacic, Spectrochim. Acta A 1967, 23, 183.

[41] É. Balogh-Hergovich, J. Kaizer, G. Speier, Inorg. Chim. Acta 1997, 256, 9.

[42] É. Balogh-Hergovich, J. Kaizer, G. Speier, G. Huttner, L. Zsolnai, Inorg. Chim. Acta 2000, 304, 72.

[43] S. Sumathi, P. Tharmaraj, C. Sheela, R. Ebenezer, J. Coord. Chem. 2011, 64, 1707.

[44] R. S. Naidu, R. R. Naidu, J. Inorg. Nucl. Chem. 1979, 41, 1625.

[45] A. Messerschmidt in Comprehensive Natural Products II, Vol. 8. (Eds.: L. Mander, H. W. Liu), Elsevier Inc, 2010, pp. 489-545.

[46] G. Izzet, J. Zeitouny, H. Akdas-Killig, Y. Frapart, S. Ménage, B. Douziech, I. Jabin, Y. Le Mest, O. Reinaud, J. Am. Chem. Soc. 2008, 130, 9514.

[47] T. Rosu, E. Pahontu, C. Maxim, R. Georgescu, N. Stanica, A. Gulea, Polyhedron 2011, 30, 154.
[48] S. Tabti, A. Djedouani, D. Aggoun, I. Warad, S. Rahmouni, S. Romdhane, H. Fouzi, J. Mol. Struct. 2018, 1155, 11.

[49] S. Mattar, B. Scharf, S. Kent, K. Rodewald, D. Oesterhelt, M. Engelhard, J. Biol. Chem. 1994, 269, 14939.

[50] B. R. Reinhammar, Biochim. Biophys. Acta 1972, 275, 245.

[51] S. Sarkar, A. Sim, S. Kim, H. I. Lee, J. Mol. Catal. A: Chem. 2015, 410, 149.

[52] K. S. Banu, T. Chattopadhyay, A. Banerjee, S. Bhattacharya, E. Suresh, M. Nethaji, E. Zangrando, D. Das, Inorg. Chem. 2008, 47, 7083.

[53] Á. Kupán, J. Kaizer, G. Speier, M. Giorgi, M. Réglier, F. Pollreisz, J. Inorg. Biochem. 2009, 103, 389.

[54] M. K. Panda, M. M. Shaikh, R. J. Butcher, P. Ghosh, Inorg. Chim. Acta 2011, 372, 145.

[55] D. Dey, S. Das, H. R. Yadav, A. Ranjani, L. Gyathri, S. Roy, P. S. Guin, D. Dhanasekaran, A. R. Choudhury, M. A. Akbarsha, Polyhedron 2016, 106, 106.

[56] S. Harmalker, S. E. Jones, D. T. Sawyer, Inorg. Chem. 1983, 22, 2790.

[57] S. K. Dey, A. Mukherjee, Coord. Chem. Rev. 2016, $310,80$.

[58] J. Kaizer, T. Csay, G. Speier, M. Giorgi, J. Mol. Catal. A: Chem. 2010, 329, 71.

[59] C. Belle, C. Beguin, I. Gautier-Luneau, S. Hamman, C. Philouze, J. Pierre, F. Thomas, S. Torelli, E. SaintAman, M. Bonin, Inorg. Chem. 2002, 41, 479.

[60] X. Wang, J. Ding, J. J. Vittal, Inorg. Chim. Acta 2006, 359, 3481.

[61] M. E. Bodini, G. Copia, R. Robinson, D. T. Sawyer, Inorg. Chem. 1983, 22, 126. 